University of Nebraska - Lincoln

DigitalCommons@University of Nebraska - Lincoln

USGS Staff -- Published Research

US Geological Survey

2012

Remote sensing of sagebrush canopy nitrogen

Jessica J. Mitchell

Idaho State University, mitcjess@isu.edu

Nancy F. Glenn

Idaho State University, glennanc@isu.edu

Temuulen T. Sankey

Idaho State University, sankteki@isu.edu

DeWayne R. Derryberry

Idaho State University

Matthew J. Germino

U.S. Geological Survey, mgermino@usgs.gov

Follow this and additional works at: https://digitalcommons.unl.edu/usgsstaffpub

Mitchell, Jessica J.; Glenn, Nancy F.; Sankey, Temuulen T.; Derryberry, DeWayne R.; and Germino, Matthew J., "Remote sensing of sagebrush canopy nitrogen" (2012). USGS Staff -- Published Research. 557. https://digitalcommons.unl.edu/usgsstaffpub/557

This Article is brought to you for free and open access by the US Geological Survey at DigitalCommons@University of Nebraska - Lincoln. It has been accepted for inclusion in USGS Staff -- Published Research by an authorized administrator of DigitalCommons@University of Nebraska - Lincoln. 


\title{
Remote sensing of sagebrush canopy nitrogen
}

\author{
Jessica J. Mitchell ${ }^{a, *}$, Nancy F. Glenn ${ }^{a}$, Temuulen T. Sankey ${ }^{a, *}$, DeWayne R. Derryberry ${ }^{b}$, Matthew J. Germino ${ }^{\text {c }}$ \\ a Department of Geosciences, Idaho State University, Boise Center Aerospace Lab, 322 E Front St., Suite 2240, Boise, ID 83702, USA \\ b Department of Mathematics, Idaho State University, PO Box 8085 Pocatello, ID 83209, USA \\ c U.S. Geological Survey (USGS), Forest and Rangeland Ecosystem Science Center, 970 Lusk St., Boise, ID 83706, USA
}

\section{A R T I C L E I N F O}

\section{Article history:}

Received 7 July 2011

Received in revised form 1 May 2012

Accepted 5 May 2012

Available online 12 June 2012

\section{Keywords:}

nitrogen

hyperspectral

continuum removal

derivative analysis

sagebrush

\begin{abstract}
A B S T R A C T
This paper presents a combination of techniques suitable for remotely sensing foliar Nitrogen $(\mathrm{N})$ in semiarid shrublands - a capability that would significantly improve our limited understanding of vegetation functionality in dryland ecosystems. The ability to estimate foliar $\mathrm{N}$ distributions across arid and semi-arid environments could help answer process-driven questions related to topics such as controls on canopy photosynthesis, the influence of $\mathrm{N}$ on carbon cycling behavior, nutrient pulse dynamics, and post-fire recovery. Our study determined that further exploration into estimating sagebrush canopy $\mathrm{N}$ concentrations from an airborne platform is warranted, despite remote sensing challenges inherent to open canopy systems. Hyperspectral data transformed using standard derivative analysis were capable of quantifying sagebrush canopy $\mathrm{N}$ concentrations using partial least squares (PLS) regression with an $R^{2}$ value of 0.72 and an $R^{2}$ predicted value of $0.42(n=35)$. Subsetting the dataset to minimize the influence of bare ground $(n=19)$ increased $R^{2}$ to $0.95\left(R^{2}\right.$ predicted $\left.=0.56\right)$. Ground-based estimates of canopy $\mathrm{N}$ using leaf mass per unit area measurements (LMA) yielded consistently better model fits than ground-based estimates of canopy $\mathrm{N}$ using cover and height measurements. The LMA approach is likely a method that could be extended to other semiarid shrublands. Overall, the results of this study are encouraging for future landscape scale $\mathrm{N}$ estimates and represent an important step in addressing the confounding influence of bare ground, which we found to be a major influence on predictions of sagebrush canopy $\mathrm{N}$ from an airborne platform.
\end{abstract}

(c) 2012 Elsevier Inc. All rights reserved.

\section{Introduction}

Dryland ecosystems are extremely vulnerable to desertification and account for roughly $40 \%$ of the Earth's land surface (e.g., Mortimore, 2009). This paper presents a combination of techniques that are suitable for remotely sensing foliar Nitrogen $(\mathrm{N})$ in semiarid shrublands - a capability that would significantly improve our limited understanding of vegetation functionality in dryland ecosystems. Whereas vegetation indices such as Modified Soil-Adjusted Vegetation Index (MSAVI) attempt to quantify vegetation abundance, estimates of foliar $\mathrm{N}$ across arid and semi-arid environments could help answer process-driven questions related to topics such as controls on canopy photosynthesis (Polley et al., 2010) and the influence of $\mathrm{N}$ on carbon cycling behavior. Also, in systems where soil water is the primary limiting resource and influenced by changes in available $\mathrm{N}$ (Inouye, 2006), there is opportunity for remote sensing of foliar $\mathrm{N}$ to augment studies related to nutrient pulse dynamics and post-fire recovery.

\footnotetext{
* Corresponding authors at: Department of Geosciences, Idaho State University, Boise Center Aerospace Lab, 322 E Front St., Suite 240, Boise, ID 83702, USA. Tel.: + 1208781 1488; fax: + 12083458353 .

E-mail address: mitcjess@isu.edu (J.J. Mitchell).
}

Remote sensing of sagebrush $\mathrm{N}$, in particular, can yield assessments of forage nutritional status across large areas. Sagebrush (Artemisia spp.) communities constitute the largest temperate semi-desert in North America and occupy approximately 60 million hectares of rangelands in the western US including the Great Basin (Anderson \& Inouye, 2001). Sagebrush communities provide important habitat for wildlife and rangelands for livestock. Sagebrush species are the dominant or codominant species of over 40 habitat types (Blaisdell et al., 1982; Monsen et al., 2004), where they provide food and cover necessary for over 350 wildlife species including Greater Sage Grouse (Centrocercus urophasianus) (Suring et al., 2005).

Studies have been surprisingly successful at estimating leaf and canopy $\mathrm{N}$ from reflectance measurements despite challenges associated with radiosity modeling of leaf $\mathrm{N}$ (Kokaly et al., 2009) and spectral discrimination of sagebrush and semi-arid backgrounds (Mundt et al., 2006a; Okin et al., 2001). A growing number of remote sensing studies have used airborne hyperspectral imagery to directly estimate canopy biochemistry in forested (e.g., Martin \& Aber, 1997; Martin et al., 1998; Matson et al., 1994; Smith et al., 2002; Townsend et al., 2003; Wessman et al., 1989) and open canopy landscapes (Huang et al., 2004; Mutanga et al., 2004; Serrano et al., 2002; Skidmore et al., 2010) using reflectance spectroscopy techniques developed empirically in the laboratory. Near-infrared spectroscopy (NIRS) is highly accurate at predicting the abundance of organic compounds in dry foliage (e.g., 
Bolster et al., 1996; Curran, 1989; Curran et al., 2001; Petisco et al., 2006) despite the relationship between reflectance variation and plant material composition being complicated by similar and overlapping absorption features (Barton et al., 1992; Kokaly \& Clark, 1999; Kumar et al., 2001). Techniques in NIRS are successful enough to have replaced wet chemistry as the biochemical assay standard in food and agricultural industries (Williams \& Norris, 1987).

Laboratory spectroscopy studies of $\mathrm{N}$ traditionally apply derivative transformations to smoothed reflectance data (i.e. logarithm of the inverse of reflectance) to minimize noise and background signal variation and resolve overlapping absorption features (Hruschka, 1987). Kokaly and Clark (1999) illustrated the use of continuum removed reflectance and band normalization (Clark \& Roush, 1984) to reduce the effects of leaf water, soil background, sensor noise, bandwidth, and atmosphere on biochemical estimations at field and remote sensing scales. While this Kokaly and Clark study cautions the need to develop remote sensing algorithms that remove the influence of water, the methodologies are intended to be less sensitive to the influence of soil background than traditional methods. In fact, linear mixture modeling in the study indicated $\mathrm{N}$ estimates were insensitive to soil background until soil cover exceeded $40 \%$. Spectral transformation techniques for estimating foliar biochemistry with relatively low sensitivity to partial canopy coverage hold particular promise in semiarid landscapes, where changes in leaf chemistry are not thought to translate to landscape level detection unless cover exceeds 70\% (Asner et al., 2000).

Overall, current literature indicates that sagebrush appears to be a viable candidate for retrieving biochemical information from subtle absorption features associated with $\mathrm{N}$ concentration. Kokaly et al. (2003) analyzed broad absorption features using continuum removal for vegetation mapping purposes. The authors reported late summer sagebrush samples had relatively low water and chlorophyll content and relatively strong absorption features related to constituents such as nitrogen, lignin and cellulose at 2100 and $2300 \mathrm{~nm}$. A study of sagebrush $\mathrm{N}$ conducted at the field scale (Mitchell et al., 2012) reported encouraging results when estimating $\mathrm{N}$ concentrations using spectroradiometer data collected over individual shrub canopies and transformed using standard derivative analysis. The field spectroscopy study determined that leaf water and a known $\mathrm{N}$ absorption feature near $2180 \mathrm{~nm}$ accounted significantly for variations in $\mathrm{N}$ concentration in the live shrub dataset analyzed.

The primary objective of our study was to determine if sagebrush canopy signals are strong enough to support detection of sagebrush canopy $\mathrm{N}$ from an airborne hyperspectral platform. The bare ground, wood, litter and soil crust that surround sagebrush crowns contribute to high albedo, which is further exacerbated by the vertical leaves and grey trichome leaf hair of sagebrush and lack of an optically dense vegetation target. Consequently, expression of $\mathrm{N}$ information at the canopy scale is likely weak and the results are largely dependent on factors such as bare ground percent cover and methods of scaling from the leaf-level to the plot or whole canopy-level. Thus, a second objective of our study was to compare how two different methods for estimating whole canopy-level $\mathrm{N}$ affect agreement between wavelength predictors and $\mathrm{N}$ concentrations in sparse desert shrubland. The first method estimates phytomass by expressing cover on a mass basis using dry leaf mass per area (LMA) ratio (e.g. Smith et al., 2002) while the second method estimates phytomass using a shrub volume surrogate that combines absolute cover and height (Serrano et al., 2002).

\section{Materials and Methods}

\subsection{Study Area}

The study area is located in a cold desert sagebrush-steppe environment on the Department of Energy, Idaho National Laboratory
(INL) in eastern Idaho. The sampling area consists of all land within an $805 \mathrm{~m}$ radius of an unmanned aerial vehicle test runway $\left(43^{\circ}\right.$ $35^{\prime} \mathrm{N}$; $-112^{\circ} 54^{\prime} \mathrm{W}$ ), with elevations ranging from approximately $1479 \mathrm{~m}$ to $1496 \mathrm{~m}$. Wyoming big sagebrush (Artemisia tridentata subsp. wyomingensis) is the dominant shrub, while basin big sagebrush (Artemisia tridentata subsp. tridentata) occurs in depressional areas and drainage channels. The sagebrush species have both persistent and ephemeral leaves that are vertical with fine grey trichome hair. The canopies have relatively sparse leaves with many woody stems covered by rough grey bark. Collectively, these characteristics contribute to spectrally indeterminate signals of sagebrush. Other species common to the area include yellow rabbitbrush (Chrysothamnus viscidiflorus), pricklypear cactus (Opuntia spp.) and crested wheatgrass (Agropyron cristatum). Air tends to be relatively dry (the average annual precipitation is $285 \mathrm{~mm}$ ) and the area experiences extreme diurnal and seasonal fluctuations in ground temperature, with an average daily temperature that ranges from $-12.22^{\circ} \mathrm{C}$ in January to $21.11{ }^{\circ} \mathrm{C}$ in July (DOE-ID, 1989). Plant water stress in this ecosystem is minimal in the spring and early summer, increases during the mid and late summer, and is greatest in August (DePuit \& Caldwell, 1973). Accordingly, sagebrush crude protein content is usually highest in the spring and gradually decreases into winter. Local precipitation records for summer 2010 are consistent with these trends. Total precipitation recorded by the Atomic City NOAA mesonet station for the months of May, June, and July 2010 were 37,17 , and $12 \mathrm{~mm}$, respectively.

\subsection{Field data collection and analysis}

A roaming ground survey was conducted from 09 August 2010 to 10 August 2010 to sample a total of 35 square plots $(7 \mathrm{~m} \mathrm{X} 7 \mathrm{~m}$ ) for percent cover (sagebrush, shrubs other than sagebrush, grass/ herbaceous, bare ground, and dead wood), average sagebrush height and foliar $\mathrm{N}$ content. Plots were located in places where bare ground and sagebrush were the dominant land cover features. Understory vegetation, grasses, and other shrubs were minimized to control for the influence of non-target vegetation. It should be noted that forbes and grasses were senescing at the time of field sampling, and that litter and surface crusts were not green. For each plot, locations were recorded for two opposite corners using a Wide Area Augmentation System (WAAS) enabled Trimble GeoXT (Sunnyvale CA) model GPS receiver and locations were differentially corrected using GPS Pathfinder software (v3.10, Trimble Navigation Limited, Sunnyvale CA). Post-processed point data from this GPS unit is capable of sub-meter positional accuracy (Serr et al., 2006). To calculate percent cover, the $7 \mathrm{~m} \mathrm{X} 7 \mathrm{~m}$ plots were divided into 49 subplots ( $1 \mathrm{~m} \mathrm{X} 1 \mathrm{~m})$ and dominant cover was recorded for each subplot. Average sagebrush height was estimated for each plot by measuring all shrubs in the plot from the ground level to the highest point of stem growth, then averaging all sagebrush height measurements. Foliar $\mathrm{N}$ content was analyzed by collecting green-leaf samples from four randomly-selected sagebrush shrubs in each plot. Two long stem specimens (approximately $40 \mathrm{~cm}$ in length) containing representative leaf forms (i.e., ephemeral and persistent) were clipped from the top of each sagebrush and air dried for several days until laboratory analysis. The four specimens collected from each plot were combined into single samples, prepared, and analyzed for leaf level $\mathrm{N}$ concentrations of ovendried ground foliage ( $\mathrm{g} \mathrm{N} / 100 \mathrm{~g}$ sample) using a Leico TrueSpec CN analyzer (St. Joseph, MI).

We scaled $\mathrm{N}$ concentrations from leaf level to plot level (total sagebrush canopy within $7 \mathrm{~m} \mathrm{X} 7 \mathrm{~m}$ plots) by adapting Smith and Martin's (2001) plot-based method for estimating forest canopy chemistry to a shrub environment. Smith and Martin's approach has been implemented in several remote sensing studies to rapidly estimate forest canopy $\mathrm{N}$ (e.g., Martin \& Aber, 1997; Ollinger \& Smith, 2005; Smith et al., 2002; Townsend et al., 2003) by weighting the fraction of canopy foliar mass per species by the mean foliar $\mathrm{N}$ concentrations for each species in a stand. In these studies, each species contribution to total canopy mass 
was determined by combining species LMA measurements with camerabased sampling methods to estimate relative fraction of leaf area by height (usually $2 \mathrm{~m}$ increments) and species. Our study assumed a single shrub stratum and calculated plot level $\mathrm{N}$ by combining sagebrush percent cover and leaf level $\mathrm{N}$ concentrations in each plot with a mean LMA measurement for big sagebrush (Artemisia tridentata spp.). A single mean LMA measurement was obtained by averaging LMA measurements collected from the leaves of 36 independent samples collected from the same study area in summer 2009 (Mitchell et al., 2012). Single-sided leaf area was measured using a Li-COR Biosciences area meter (model LI-3100; Lincoln, Nebraska). Samples were then oven dried $\left(60^{\circ} \mathrm{C}\right.$ for 72 hours), ground in a Wiley mill, passed through a 1-mm mesh screen, and weighed to the nearest $0.1 \mathrm{mg}$. The average single sided leaf area was $1.12 \mathrm{~cm}^{2}$, with a standard deviation of $0.25 \mathrm{~cm}^{2}$ and the average dry weight was $9.68 \mathrm{mg}$ with a standard deviation of $1.87 \mathrm{mg}$. We also tested an alternative plot-level sagebrush canopy $\mathrm{N}$ calculation whereby sagebrush foliar $\mathrm{N}$ concentration is weighted by a shrub volume surrogate: the product of absolute cover and mean height (Serrano et al., 2002). This alternative method for calculating sagebrush canopy $\mathrm{N}$ is hereafter referred to as 'bulk canopy N'.

\subsection{HyMap Data}

On 13 August 2010, an airborne HyMap sensor (operated by HyVista, Inc., Sydney, Australia) collected two overlapping flightlines $\left(\approx 11 \mathrm{~km}^{2}\right.$ total) of hyperspectral imagery approximately $2496 \mathrm{~m}$ above ground level with a nominal pixel resolution of $2.1 \mathrm{~m}$. The sensor collects calibrated radiance data in 126 near-contiguous spectral bands (450-2480 nm) that range in width from $15 \mu \mathrm{m}$ in the visible and nearinfrared to $20 \mu \mathrm{m}$ in the shortwave infrared (Cocks et al., 1989). The radiance values were converted by the vendor to apparent reflectance using the HyCorr (Hyperspectral Correction) absolute atmospheric correction modeling package, which is based on the Atmospheric Removal Program (ATREM; Gao \& Goetz, 1990; ATREM, 1992). A total of 14 ground control points collected throughout the imagery were used to assess HyMap georegistration error. Directional shifts occurred nonuniformly, with a combined root mean square errors (RMSE) of $2.8 \mathrm{~m}$ for the two flightlines. Reflectance spectra were extracted from square sample plot polygons $(7 \mathrm{~m} \mathrm{X} 7 \mathrm{~m}$ ) by averaging the pixels (ranging from 9-11 pixels) with area majority inside the plots. The following regions were removed from the data due to noise and water absorption: 1390-1419, 1796-1948, and 2472-2487 nm.

\subsection{Spectral data processing}

HyMap reflectance data (Fig. 1) were transformed using two different approaches, 1) standard derivative analysis and 2) band depth analysis of continuum removed absorption feature spectra. For the first approach, first derivative of log transformed reflectance (FDR) [ $\log _{10}$ $(1 / R)$ ] was implemented in ViewSpec Pro $^{\mathrm{TM}}$ (v6.0 ASD, Inc., Boulder, CO) using log transformed HyMap reflectance spectra as input. The calculation of the log transformation of reflectance uses a polynomial interpolation, Neville's algorithm (Press et al., 1992), from which new HyMap reflectance datasets, interpolated at $1 \mathrm{~nm}$ wavelength intervals, are generated. The interpolation performed in ViewSpec Pro ${ }^{\mathrm{TM}}$. The log transformed HyMap reflectance datasets were then used as input in the subsequent first derivative reflectance calculation, which uses the following equation:

$\operatorname{FDR}(\lambda)=\frac{[\mathrm{F}(\lambda+\Delta \lambda)-\mathrm{F}(\lambda-\Delta \lambda)]}{2 \Delta \lambda}$

where $\mathrm{F}$ and $\operatorname{FDR}(\lambda)$ is first derivative reflectance, or slope value. First derivative reflectance was therefore calculated every $1 \mathrm{~nm}$ by differencing wavelengths, specified in this analysis as the three sample points on either side of the wavelength being calculated. The three point analysis is

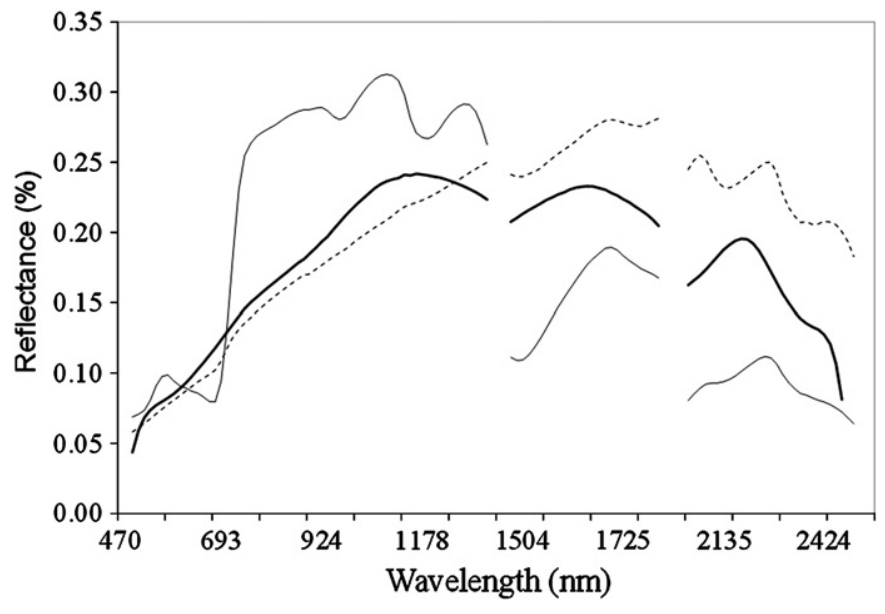

Fig. 1. Average reflectance spectra of sample plots $(7 \mathrm{~m}$ X $7 \mathrm{~m}$ ) extracted from HyMap data (thick line) and field spectrometer measurements (Mitchell et al., 2012) of individual big sagebrush (Artemisia tridentata spp.) canopy (thin line) and bare ground (dashed line). Field spectrometer measurements were collected on and in the vicinity of the study area July 2009 (Mitchell et al., 2012) using a FieldSpec® Pro (Analytical Spectral Devices, Inc., Boulder CO, USA). Bands removed due to noise and water absoprtion not depicted.

the smallest wavelength gap ( $7 \mathrm{~nm}$ ) in ViewSpec Pro $^{\mathrm{TM}}$ and was selected to avoid masking narrow absorption features that may be related to $\mathrm{N}$ concentration.

For the second approach, continuum removal was used to estimate then remove absorptions not related to the feature of interest (Clark \& Roush, 1984) while band depth normalization (to the band center) was used to compare the shape of absorption features. Changes in shape are correlated to foliar chemistry - for example, a broadening of the absorption feature at $2100 \mathrm{~nm}$ occurs with an increase in $\mathrm{N}$ concentration (Kokaly, 2001). Continuum removal was applied to select wavelength intervals with known $\mathrm{N}$ associations (Curran, 1989) using Spectral Library Builder in ENVI 4.7 (ITT Visual Information Solutions, 2010). We isolated five absorption features for continuum removal (Table 1 ) by collectively examining HyMap reflectance spectra to identify local spectral maxima. Normalized band depths were then calculated for each wavelength in the continuum removed intervals following methods described in Kokaly and Clark (1999). For each sample, we expressed normalized band depth in terms of the band depth normalized to the wavelength at the center of the absorption feature (CR) using the formula:

$\mathrm{CR}=\frac{1-\left(\frac{R}{R \mathrm{i}}\right)}{1-\left(\frac{R \mathrm{c}}{R \mathrm{ic}}\right)}$

where $R$ is the reflectance value at the waveband of interest, $R_{\mathrm{i}}$ is the continuum removed reflectance value for the waveband of interest, $R_{\mathrm{C}}$ is the reflectance value at the center of the absorption feature, and $R_{\mathrm{ic}}$ is the continuum removed reflectance value at the center of the absorption feature.

Table 1

The location of absorption features selected for continuum removal (CR) along with absorption features of known association with $\mathrm{N}$ in dried, ground leaves, as reported by Curran (1989).

\begin{tabular}{lll}
\hline $\begin{array}{l}\text { Short wavelength } \\
\text { endpoint }(\mathrm{nm})\end{array}$ & $\begin{array}{l}\text { Long wavelength } \\
\text { endpoint }(\mathrm{nm})\end{array}$ & $\begin{array}{l}\text { Known } \mathrm{N} \text { absorption fea- } \\
\text { tures }(\mathrm{nm})\end{array}$ \\
\hline $\begin{array}{l}\text { HyMap plot spectra }(n=35) \\
531\end{array}$ & 708 & 640,660 \\
1001 & 1091 & 1020 \\
1663 & 1738 & 1690 \\
2005 & 2205 & $2060,2130,2180$ \\
2241 & 2392 & 2240,2300 \\
\hline
\end{tabular}




\subsection{Relating spectral measurements to foliar nitrogen concentrations}

We used partial least squares (PLS) regression to relate transformed HyMap wavebands (FDR and CR) to plot level N concentration estimates. We chose PLS over stepwise regression because PLS regression is commonly used in chemometric applications with large numbers of predictor variables (e.g. wavelengths). Also, stepwise regression has been criticized in live vegetation studies for dependency on the dataset being used and selection of wavebands that are either physically unrelated to absorption features associated with the biochemical being tested or correlated to other biochemicals (Curran et al., 1992; Grossman et al., 1996; Johnson et al., 1994; Martin \& Aber, 1997). A PLS approach is in following with several recent and related remote sensing studies that have either evaluated (Huang et al., 2004) or used PLS regression (Ollinger \& Smith, 2005; Ollinger et al., 2008; Smith et al., 2002; Townsend et al., 2003) to relate wavebands to biochemical concentrations.

Eight dataset combinations were considered independently of each other in our regression analyses to test the influence of spectral transformation techniques, sagebrush canopy $\mathrm{N}$ estimation methods, and bare ground cover on model fit. First, two different variations of the set of predictor variables were considered: wavelengths transformed using CR and wavelengths transformed using FDR. These two variations were then combined with four variations of the canopy $\mathrm{N}$ response variable: canopy $\mathrm{N}$ calculated using LMA, canopy $\mathrm{N}$ calculated using the bulk canopy $\mathrm{N}$ alternative, and subsets of each with bare ground cover $<40 \%$ ( $n=19$ plots).

All PLS regressions were implemented in Minitab version 15.1.30.0 software (Minitab, Inc., State College, PA) using the nonlinear iterative partial least squares (NIPALS) algorithm and leave-one-out cross validation was used to select a "best" model based on an optimal number of components that maximizes the model's predictive ability. The optimal number of model components was limited to eight to avoid overfitting. Prediction error sum of squares (PRESS) and predicted coefficient of determination ( $R^{2}$ predicted) values are reported. $R^{2}$ predicted values are more conservative than $R^{2}$ values and penalize overfitting, which is directly related to a model's predictive ability. An $R^{2}$ predicted value therefore provides a sense of how well a regression equation would predict $\mathrm{N}$ concentrations using a new dataset, presumably from a different study area. Due to software constraints, the full continuum of wavelengths $(n=1997)$ used as predictor variables in the FDR-transformed models were reduced by first calculating regression coefficients between each wavelength and $\mathrm{N}$ response variable, then visually selecting wavelengths with the highest absolute coefficients $(n=738$ ) using coefficient plots. For all PLS regression datasets, wavelengths of interest were identified based on standardized regression coefficients generated in the best PLS regression models. Wavelength selection was evaluated in the context of association with known $\mathrm{N}$ foliar chemistry, such as nitrogen bonds in proteins.

\section{Results and Discussion}

The sample plots in our study contained a range of sagebrush (22-71\%) and bare ground (14-65\%) cover estimates, which resulted in plot level ( 7 m X 7 m) whole canopy calculations of sagebrush N concentration that varied from 0.37 to $1.18 \%$ (Table 2). Reflectance spectra extracted from sample plots within the HyMap data reveal a high degree of mixing (Fig. 1). Bare ground, exposed and senescent herabaceous understory, litter and dead wood obscure absorption features related to chlorophyll (centered near 480 and $680 \mathrm{~nm}$ ). In contrast, these absorption features are characteristically pronounced in the reflectance spectra of live vegetation, as illustrated in Fig. 1 by the spectra of sagebrush canopy collected in the study area (Mitchell et al., 2012) with a FieldSpec ${ }^{\circledR}$ Pro (Analytical Spectral Devices, Inc. Boulder, CO USA) field spectrometer in July 2009 under cloud-free conditions, similar to that of the HyMap acquisition. The influence of drier vegetation is also evidenced in the HyMap
Table 2

Summary of field data collected for each sample plot $\left(49 \mathrm{~m}^{2}\right)$ : percent land cover, average sagebrush height, and $\mathrm{N}$ concentration measured at the leaf level (dried, ground) and estimated at the whole canopy level using leaf mass per unit area (LMA) measurements.

\begin{tabular}{|c|c|c|c|c|c|c|c|c|}
\hline Plot & $\begin{array}{l}\text { Sagebrush } \\
\text { (\% cover) }\end{array}$ & $\begin{array}{l}\text { Shrub } \\
\text { (other) } \\
\text { (\% } \\
\text { cover) }\end{array}$ & $\begin{array}{l}\text { Bare } \\
\text { ground } \\
\text { (\% } \\
\text { cover) }\end{array}$ & $\begin{array}{l}\text { Herb. } \\
(\% \\
\text { cover })\end{array}$ & $\begin{array}{l}\text { Dead } \\
\text { wood } \\
(\% \\
\text { cover })\end{array}$ & $\begin{array}{l}\text { Avg. } \\
\text { sagebrush } \\
\text { height } \\
(\mathrm{cm})\end{array}$ & $\begin{array}{l}\text { Leaf } \\
\mathrm{N} \\
(\%)\end{array}$ & $\begin{array}{l}\text { Canopy } \\
\mathrm{N}(\%)\end{array}$ \\
\hline 1 & 31 & 0 & 39 & 27 & 4 & 73 & 2.78 & 0.50 \\
\hline 2 & 47 & 0 & 41 & 6 & 6 & 70 & 2.59 & 0.97 \\
\hline 3 & 35 & 2 & 39 & 18 & 6 & 58 & 2.19 & 0.62 \\
\hline 4 & 33 & 0 & 49 & 16 & 2 & 79 & 2.78 & 0.59 \\
\hline 5 & 41 & 2 & 33 & 10 & 14 & 58 & 2.53 & 0.72 \\
\hline 6 & 65 & 0 & 29 & 4 & 2 & 53 & 2.34 & 0.94 \\
\hline 7 & 51 & 2 & 24 & 14 & 8 & 56 & 2.07 & 0.86 \\
\hline 8 & 22 & 8 & 47 & 14 & 8 & 80 & 2.16 & 0.43 \\
\hline 9 & 39 & 0 & 47 & 6 & 8 & 89 & 1.85 & 0.65 \\
\hline 10 & 39 & 4 & 47 & 2 & 8 & 72 & 2.09 & 0.68 \\
\hline 11 & 41 & 0 & 49 & 0 & 10 & 68 & 1.61 & 0.70 \\
\hline 12 & 71 & 0 & 14 & 10 & 4 & 43 & 2.12 & 1.06 \\
\hline 13 & 39 & 2 & 43 & 8 & 8 & 58 & 2.33 & 0.52 \\
\hline 14 & 65 & 0 & 29 & 2 & 4 & 52 & 2.08 & 1.03 \\
\hline 15 & 53 & 0 & 18 & 18 & 10 & 57 & 1.67 & 0.83 \\
\hline 16 & 45 & 2 & 22 & 24 & 6 & 51 & 2.23 & 0.70 \\
\hline 17 & 45 & 0 & 37 & 12 & 6 & 59 & 2.04 & 0.71 \\
\hline 18 & 71 & 0 & 24 & 2 & 2 & 52 & 1.95 & 1.18 \\
\hline 19 & 49 & 0 & 39 & 4 & 8 & 42 & 2.28 & 0.74 \\
\hline 20 & 49 & 2 & 18 & 16 & 14 & 55 & 2.35 & 0.77 \\
\hline 21 & 55 & 0 & 31 & 6 & 8 & 49 & 1.71 & 0.82 \\
\hline 22 & 47 & 2 & 31 & 4 & 16 & 52 & 2.41 & 0.83 \\
\hline 23 & 37 & 2 & 35 & 14 & 12 & 67 & 2.34 & 0.61 \\
\hline 24 & 49 & 2 & 33 & 10 & 6 & 49 & 1.54 & 0.80 \\
\hline 25 & 29 & 0 & 65 & 4 & 2 & 53 & 1.89 & 0.48 \\
\hline 26 & 37 & 0 & 57 & 0 & 6 & 38 & 1.77 & 0.60 \\
\hline 27 & 27 & 0 & 45 & 4 & 24 & 53 & 2.25 & 0.42 \\
\hline 28 & 41 & 4 & 45 & 6 & 4 & 44 & 2.33 & 0.61 \\
\hline 29 & 43 & 0 & 51 & 2 & 4 & 38 & 2.15 & 0.66 \\
\hline 30 & 37 & 0 & 33 & 18 & 12 & 47 & 1.90 & 0.55 \\
\hline 31 & 39 & 2 & 33 & 16 & 10 & 53 & 1.92 & 0.60 \\
\hline 32 & 35 & 0 & 45 & 12 & 8 & 59 & 2.04 & 0.47 \\
\hline 33 & 31 & 0 & 45 & 16 & 8 & 61 & 2.52 & 0.45 \\
\hline 34 & 24 & 0 & 51 & 20 & 4 & 52 & 1.88 & 0.37 \\
\hline 35 & 47 & 0 & 49 & 0 & 4 & 73 & 2.74 & 0.69 \\
\hline
\end{tabular}

spectra by a gradual (rather than a steep) increase in reflectance values near the red-edge (near $750 \mathrm{~nm}$ ).

PLS regression model results varied, with $R^{2}$ values ranging from 0.37 to 0.97 and $R^{2}$ predicted values ranging from 0.0 to 0.56 (Table 3 ). These results are consistent with previous studies that have used remote sensing to estimate canopy $\mathrm{N}$ in open (Serrano et al., 2002) and closed canopy (e.g.; Huang et al., 2004; Martin et al., 2008; Ollinger \& Smith, 2005; Ollinger et al., 2008) environments. The $R^{2}$ values in these studies ranged from 0.57 to 0.99 . The Kokaly and Clark continuum removal methodology has consistently outperformed FDR in previous studies using dry and fresh plant spectra, with $R^{2}$ values ranging from 0.43 to 0.85 (e.g., Curran et al., 2001; Huang et al., 2004; Mutanga et al., 2004). In this study, regression models using continuum removal produced $R^{2}$ values ranging from 0.37 to $0.65\left(R^{2}\right.$ predicted $\left.0.00-0.19\right)$, while we obtained higher $R^{2}$ values using FDR, with values ranging from 0.55 to $0.72\left(R^{2}\right.$ predicted $0.26-0.56$ ).

Overall, PLS regression results suggest that bare ground cover has a major influence on the ability to remotely estimate sagebrush canopy $\mathrm{N}$ concentration. Compared to CR-transformed datasets, FDRtransformed datasets appeared more sensitive to changes in bare ground cover, as subsetting plots (from $n=35$ to $n=19$ ) on the basis of bare ground cover accounted for major differences in model performance. These differences are considered valid despite the small sample size of the bare ground $<40 \%$ subset $(n=19)$ because of both the large number of components extracted and the high $R^{2}$ predicted (Table 3 ). When the influence of bare ground was minimized in the FDR datasets by subsetting the data to include only 
Table 3

Partial least square regression results for relating foliar $\mathrm{N}$ concentrations to HyMap spectra extracted from field plots ( $7 \mathrm{~m} \mathrm{X} 7 \mathrm{~m} ; n=35$ ). Prediction error sum of squares (PRESS) and $R^{2}$ predicted values are reported.

\begin{tabular}{|c|c|c|c|c|c|}
\hline Dataset & $\begin{array}{l}\text { No. of PLS } \\
\text { components }\end{array}$ & $R^{2}$ & $\begin{array}{l}R^{2} \\
\text { Predicted }\end{array}$ & PRESS & $\begin{array}{l}\text { Wavelength } \\
\text { Selection }\end{array}$ \\
\hline \multicolumn{6}{|c|}{ Spectral Transformation: Continuum Removed Reflectance } \\
\hline $\begin{array}{l}\text { Canopy } \mathrm{N} \text { estimated } \\
\text { using proportional } \\
\text { leaf area and leaf } \\
\text { mass per unit area } \\
\text { measurements } \\
(n=35)\end{array}$ & 2 & 0.65 & 0.19 & 1.02 & $\begin{array}{l}1046,1076 \\
2360^{*}, 591, \\
2343^{*}, 2117^{*}\end{array}$ \\
\hline $\begin{array}{l}\text { Canopy } \mathrm{N} \text { estimated } \\
\text { using proportional } \\
\text { leaf area and leaf } \\
\text { mass per unit area } \\
\text { measurements } \\
(n=19) \\
\text { Ground }<40 \%\end{array}$ & 1 & 0.65 & 0.18 & 0.47 & $\begin{array}{l}1016^{*}, 2117^{*}, \\
2043^{*}, \\
2062^{*}, \\
2293^{*}, 679\end{array}$ \\
\hline $\begin{array}{l}\text { Bulk Canopy } \mathrm{N} \text { (height } \\
\text { and absolute cover) } \\
(n=35)\end{array}$ & 1 & 0.37 & 0 & 1363.32 & $\begin{array}{l}1046,2343^{*} \\
546,2024 \\
2376,2360 *\end{array}$ \\
\hline $\begin{array}{l}\text { Bulk Canopy } \mathrm{N} \text { (height } \\
\text { and absolute cover) } \\
(n=19)\end{array}$ & 1 & 0.56 & 0 & 430.28 & $\begin{array}{l}2117^{*} \\
2043^{*} \\
2062^{*}\end{array}$ \\
\hline Bare Ground $<40 \%$ & & & & & $\begin{array}{l}2293^{*}, 1076 \\
1046\end{array}$ \\
\hline \multicolumn{6}{|c|}{ Spectral Transformation: First Derivative Reflectance of [ $\log _{10}(1 /$ Reflectance $\left.)\right]$} \\
\hline $\begin{array}{l}\text { Canopy } \mathrm{N} \text { estimated } \\
\text { using proportional } \\
\text { leaf area and leaf } \\
\text { mass per unit area } \\
\text { measurements } \\
(n=35)\end{array}$ & 2 & 0.72 & 0.42 & 0.74 & $\begin{array}{l}1676 *, 2024 \\
1990 *, 1076 \\
513,1151\end{array}$ \\
\hline $\begin{array}{l}\text { Canopy } \mathrm{N} \text { estimated } \\
\text { using proportional } \\
\text { leaf area and leaf } \\
\text { mass per unit area } \\
\text { measurements } \\
(n=19)\end{array}$ & 4 & 0.95 & 0.56 & 0.25 & $\begin{array}{l}808,1663 \\
2024,1675^{*} \\
503,1163\end{array}$ \\
\hline Bare Ground $<40 \%$ & & & & & \\
\hline $\begin{array}{l}\text { Bulk Canopy } \mathrm{N} \text { (height } \\
\text { and absolute cover) } \\
(n=35)\end{array}$ & 1 & 0.55 & 0.26 & 909.38 & $\begin{array}{l}1163,1749 \\
1919,1424, \\
1078,2425\end{array}$ \\
\hline $\begin{array}{l}\text { Bulk Canopy } \mathrm{N} \text { (height } \\
\text { and absolute cover) } \\
(n=19)\end{array}$ & 5 & 0.97 & 0.55 & 151.60 & $\begin{array}{l}1154,1661 \\
508,827 \\
891,1091\end{array}$ \\
\hline Bare Ground < $40 \%$ & & & & & \\
\hline
\end{tabular}

Within $20 \mathrm{~nm}$ of a known $\mathrm{N}$ absorption feature.

sample plots with cover $>40 \%, R^{2}$ values increased from 0.72 to 0.95 and from 0.55 to 0.97 . When the influence of bare ground was minimized in the CR datasets, $R^{2}$ values remained at 0.65 in the dataset that calculated canopy $\mathrm{N}$ using LMA measurements and increased from 0.37 to 0.56 in the dataset that calculated canopy $\mathrm{N}$ using the alternative bulk canopy $\mathrm{N}$ method. While the sample size in this study is not large enough to support incremental thresholding of bare ground cover (e.g., Mundt et al., 2006b), CR results support the assertion that this transformation technique is relatively insensitive to soil background (Kokaly \& Clark, 1999).

Datasets for which canopy N was calculated using LMA measurements consistently yielded better model fits than datasets for which canopy $\mathrm{N}$ was calculated using the alternative bulk canopy $\mathrm{N}$ method (Table 3). These results are logical, as a bulk estimate of canopy $\mathrm{N}$ based on height and absolute cover provides a less direct estimate than does the combination of canopy cover and LMA. Further, the latter approach expresses $\mathrm{N}$ concentration on a mass basis ( $\mathrm{g} \mathrm{N} / 100 \mathrm{~g}$ ), and mass-based $\mathrm{N}$ relationships have been noted for photosynthetic capacity (Field \& Mooney, 1986; Ollinger et al., 2008; Reich et al., 1999) and soil N availability (Pastor et al. 1984, Yin 1992, Scott \& Blinkley 1997, Smith et al. 2002).
Shorter wavelengths with high predictive potential in the $\mathrm{CR}$ and FDR-transformed datasets $(503,508,513,546,591$, and $679 \mathrm{~nm}$; Table 3 ) occur in the visible portion of the spectrum and are likely related to plant pigments such as $\beta$-carotene and chlorophyll, which are correlated to protein and therefore total N (Field \& Mooney, 1986). The majority of remaining wavelengths with high predictive potential in the CR datasets occurred within $20 \mathrm{~nm}$ of known $\mathrm{N}$ absorption features in the near- and shortwave infrared (i.e., 1016, 2043, 2062, 2117, 2293, 2360, and $2376 \mathrm{~nm}$; Table 3). Possible causal explanations include $\mathrm{N}-\mathrm{H}$ stretch at 1020, 2130 and $2300 \mathrm{~nm}, \mathrm{~N}-\mathrm{H}$ stretch and $\mathrm{N}-\mathrm{H}$ bend at $2060 \mathrm{~nm}$, and protein and nitrogen overtone at $2350 \mathrm{~nm}$. Wavelengths that have high predictive potential in the CR datasets but lack a causal explanation are limited to 1046 and $1076 \mathrm{~nm}$. The $1043 \mathrm{~nm}$ wavelength has been identified recurrently in a similar study (Huang et al., 2004). Possible explanations for identification of these wavelengths include $\mathrm{C}-\mathrm{H}$ stretch and $\mathrm{C}-\mathrm{H}$ deformation related to oil at $1040 \mathrm{~nm}$ and $\mathrm{C}-\mathrm{H}$ stretch and a second overtone related to lignin at $1120 \mathrm{~nm}$.

The majority of wavelengths with high predictive potential in the FDR-transformed datasets lack evidence of causal association with $\mathrm{N}$ (i.e., 1076, 1078, 1091, 1151, 1154, 1163, 1424, 1661, 1663, 1749, 1919,2024 , and $2425 \mathrm{~nm}$ ). This is expected since the CR datasets consist of wavelength intervals pre-selected based on known $\mathrm{N}$ absorption features, while the FDR-transformed datasets do not. Consequently, wavelength selection based on standardized coefficients for the FDRtransformed datasets may rely heavily on how much the wavelength value varies in the dataset. One such case may be the selection of wavelengths in the near infrared region (i.e., 808, 827, and $891 \mathrm{~nm}$ ). This region has been broadly shown to vary with $\% \mathrm{~N}$, likely as a result of correlations between \% $\mathrm{N}$ and leaf-to-canopy traits that influence scattering (e.g. Ollinger, 2011). The wavelength $1424 \mathrm{~nm}$ is likely related to leaf water absorption near $1400 \mathrm{~nm}$ while other wavelengths could be related to absorption features associated with constituents such as lignin, cellulose and starch. Since non-photosynthetic vegetation is largely composed of lignin and cellulose, these wavelength selection results may reflect the influence of dead matter at the plot and landscape scale in open canopy systems. Wavelengths with high predictive potential in the FDR-transformed datasets that occur within $20 \mathrm{~nm}$ of a known $\mathrm{N}$ absorption feature are limited to 1676 and $1990 \mathrm{~nm}$. The $1690 \mathrm{~nm}$ is a nitrogen and protein overtone band and N-H asymmetry related to protein occurs at $1980 \mathrm{~nm}$. Findings in our study are consistent with general findings in previous studies that report wavelength selection near relatively strong absorption features related to biochemical constituents such as nitrogen, lignin and cellulose (e.g., Curran et al., 2001; Huber et al., 2008; Johnson \& Billow, 1996; Kokaly, 2001; Kokaly \& Clark, 1999; Kokaly et al., 2003; Mutanga et al., 2004).

\section{Conclusions}

HyMap spectra transformed using standard derivative analysis was capable of quantifying sagebrush canopy $\mathrm{N}$ concentrations using PLS regression with an $R^{2}$ value of 0.72 and an $R^{2}$ predicted value of 0.42 . Subsetting the HyMap dataset to minimize the influence of bare ground increased $R^{2}$ to $0.95\left(R^{2}\right.$ predicted $\left.=0.56\right)$. Calculating canopy $\mathrm{N}$ using LMA measurements rather than bulk canopy estimates yielded consistently better model fits between wavelength predictors and plot-level $\mathrm{N}$ concentrations. A final comparison to the Serrano et al. study (2002) is revealing despite the difference in the sizes of the areas sampled. A bulk canopy approach and $20 \mathrm{~m}$ pixels may be well suited for rapid, regional estimations of $\mathrm{N}$ content in landscapes with relatively continuous cover. In contrast, a more measurement-intense leaf mass per unit area approach and $2 \mathrm{~m}$ pixels may be warranted when estimating canopy $\mathrm{N}$ across sparsely vegetated landscapes.

The implementation of spectral transformation techniques should be further refined and additional datasets should be collected in 
different study areas to improve and evaluate the predictive ability of regression models across sites. Results of this study represent an important step in addressing the confounding influence of bare ground, which we found to be a significant challenge in remote sensing of foliar $\mathrm{N}$ in semi-arid landscapes, possibly more so than leaf water. Consequently, future research should focus on image processing techniques to reduce the influence of bare ground, such as leveraging equations derived at the field/ individual shrub scale. Further consideration should also be given to the role of leaf water and plot level canopy $\mathrm{N}$ calculation methods by expanding the breadth of field data analysis. For example, green leaf specimens could be analyzed for leaf water content and LAI measurements could be collected at the shrub and plot levels. Finally, it should be noted that future efforts will need to address $\mathrm{N}$ contributions from grasses and other shrub species. This point is suggested in the derivative-transformed data, from which many of the wavelengths selected as predictors of $\mathrm{N}$ concentration were likely related to lignin, cellulose and starch. Collectively, study results are encouraging and warrant the continuation of efforts to estimate foliar $\mathrm{N}$ concentrations in open canopy systems, with the intention of further elucidating the role of dryland ecosystem vegetation in processes such a desertification and nutrient cycling.

\section{Acknowledgements}

This study was supported by grants from the Idaho Space Grant Consortium, NOAA OAR ESRL Physical Sciences Division Grant \# NA06OAR4600124, NSF Idaho EPSCOR Program and by the National Science Foundation under award number EPS-0814387. Research was also made possible through coordination and facilitation of access on the part of Matthew Anderson (Idaho National Lab) and Roger Blew (S. M. Stoller Corporation); through the use of Matt Germino's plant ecology lab, and through the field assistance provided by Carol Moore. Any use of trade, product, or firm names is for descriptive purposes only and does not imply endorsement by the U.S. Government.

\section{References}

[ATREM] Atmospheric Removal Program [computer program] (1992). Version 1.1. Boulder, CO, USA: Center for the Study of Earth from Space. : University of Colorado.

Anderson, J. E., \& Inouye, R. S. (2001). Landscape-scale changes in plant species abundance and biodiversity of a sagebrush steppe over 45 years. Ecological Monographs, 71, 531-556.

Asner, G. P., Wessman, C. A., Bateson, C. A., \& Privette, J. L. (2000). Impact of tissue, canopy, and landscape factors on the hyperspectral reflectance variability of arid environments. Remote Sensing of Environment, 30, 271-278.

Barton, F. E., Himmelsbach, D. S., Duckworth, J. H., \& Smith, M. J. (1992). Two-dimensional vibration spectroscopy: Correlation of mid- and near-infrared regions. Applied Spectroscopy, 46, 420-429.

Blaisdell, J. P., Murray, R. B., \& McArthur, E. D. (1982). Managing Intermountain rangelands -sagebrush-grass ranges. Gen. Tech. Rep. INT-134. Ogden, UT: U.S. Department of Agriculture, Forest Service, Intermountain Forest and Range Experiment Station $41 \mathrm{pp}$.

Bolster, K. L., Martin, M. E., \& Aber, J. D. (1996). Determination of carbon fraction and nitrogen concentration in tree foliage by near infrared reflectance: a comparison of statistical methods. Canadian Journal of Forest Research, 26, 590-600.

Clark, R. N., \& Roush, T. L. (1984). Reflectance spectroscopy: Quantitative analysis techniques for remote sensing applications. Journal of Geophysical Research, 89, 6329-6340.

Cocks, T., Jenssen, R., Stewart, A., Wilson, I., \& Shields, T. (1989). The HyMap airborne hyperspectral sensor: the system, calibration and performance. In M. E. Schaepman, D. Schlaepfer, \& K. I. Itten (Eds.), Proceedings of the First EARSeL Workshop on Imaging Spectroscopy (pp. 37-42). Zürich, Switzerland: EARSeL.

Curran, P. J. (1989). Remote sensing of foliar chemistry. Remote Sensing of Environment, 30, 271-278.

Curran, P. J., Dungan, J. L., Macler, B. A., Plummer, S. E., \& Peterson, D. L. (1992). Reflectance spectroscopy of fresh whole leaves for the estimation of chemical composition. Remote Sensing of Environment, 39, 153-166.

Curran, P. J., Dungan, J. L., \& Peterson, D. L. (2001). Estimating the foliar biochemical concentration of leaves with reflectance spectrometry: Testing the Kokaly and Clark Methodologies. Remote Sensing of Environment, 76, 349-359.

DePuit, E. J., \& Caldwell, M. M. (1973). Seasonal pattern of net photosynthesis of Artemisia tridentata. American Journal of Botany, 60, 426-435.

DOE-ID (1989). Climatography of the Idaho National Engineering Laboratory (2nd ed.). U.S. Department of Energy Idaho Operations Office DOE/ ID-12118.
Field, C., \& Mooney, H. A. (1986). The photosynthesis- nitrogen relationship in wild plants. In T. J. Givnish (Ed.), On the economy of plant form and function (pp. 25-55). UK: Cambridge University Press.

Gao, B., \& Goetz, A. F. H. (1990). Column atmospheric water vapor and vegetation liquid water retrievals from airborne imaging spectrometer data. Journal of Geophysical Research, 95, 3549-3564.

Grossman, Y. L., Ustin, S. L., Jacquemond, S., Sanderson, E. W., Schmuck, G., \& Verdebout, J. (1996). Critique of stepwise multiple linear regression for the extraction of leaf biochemistry information from leaf reflectance data. Remote Sensing of Environment, 56, 1-12.

Hruschka, W. R. (1987). Data analysis: wavelength selection methods. In P. Williams, \& K. Norris (Eds.), Near-Infrared Technology in the Agricultural and Food Industries (pp. 35-53). Minnesota: American Association of Cereal Chemists, Inc..

Huang, Z., Turner, B. J., Dury, S. J., Wallis, I. R., \& Foley, W. J. (2004). Estimating foliage nitrogen concentration from HyMap data using continuum removal analysis. Remote Sensing of Environment, 93, 18-29.

Huber, S., Kneubühler, M., Psomas, A., Itten, K., \& Zimmerman, N. E. (2008). Esimating foliar biochemistry from hyperspectral data in mixed forest canopy. Forest Ecology and Management, 256, 491-501.

Inouye, R. S. (2006). Effect of shrub removal and nitrogen addition on soil moisture in sagebrush steppe. Journal of Arid Environments, 65, 604-618.

ITT Visual Information Solutions (2010). ENVI - Environment for Visualizing Images. User's Guide, Version 4.7. Boulder, Colorado: Research Systems Inc.

Johnson, L. F., \& Billow, C. R. (1996). Spectrometric estimation of total nitrogen concentration I Douglas-fir foliage. International Journal of Remote Sensing, 17, 489-500.

Johnson, L. F., Hlavka, C. A., \& Peterson, D. L. (1994). Multivariate analysis of AVIRIS data for canopy biochemical estimation along the Oregon transect. Remote Sensing of Environment, 47, 216-230.

Kokaly, R. F. (2001). Investigating a physical basis for spectroscopic estimates of leaf nitrogen concentration. Remote Sensing of Environment, 75, 153-161.

Kokaly, R. F., Asner, G. P., Ollinger, S. V., Martin, M. E., \& Wessman, C. A. (2009). Characterizing canopy biochemistry from imaging spectroscopy and its application to ecosystem studies. Remote Sensing of Environment, 113, S78-S91.

Kokaly, R. F., \& Clark, R. N. (1999). Spectroscopic determination of leaf biochemistry using band-depth analysis of absorption features and stepwise multiple linear regression Remote Sensing of Environment, 67, 267-287.

Kokaly, R. F., Despain, D. G., Clark, R. N., \& Livo, K. E. (2003). Mapping vegetation in Yellowstone National Park using spectral feature analysis of AVIRIS data. Remote Sensing of Environment, 84, 437-456.

Kumar, L., Schmidt, K. S., Dury, S., \& Skidmore, A. K. (2001). Imaging spectrometry and vegetation science. In F. van der Meer, \& S. M. de Jong (Eds.), Netherlands: Kluwer Academic Publishing.

Martin, M. E., \& Aber, J. D. (1997). High spectral resolution remote sensing of forest canopy lignin, nitrogen and ecosystem process. Ecological Applications, 7, 431-443.

Martin, M. E., Newman, S. D., Aber, J. D., \& Congalton, R. G. (1998). Determining forest species composition using high spectral resolution remote sensing data. Remote Sensing of Environment, 65, 249-254.

Martin, M. E., Plourde, L. C., Ollinger, S. V., Smith, M. -L., \& McNeil, B. E. (2008). A generalizable method for remote sensing of canopy nitrogen across a wide range of forest ecosystems. Remote Sensing of Environment, 112, 3511-3519.

Matson, P. A., Johnson, L., Billow, C., Miller, J., \& Pu, R. (1994). Seasonal patterns and remote spectral estimation of canopy chemistry across the Oregon transect. Ecological Applications, 4, 280-298.

Mitchell, J. J., Glenn, N. F., Sankey, T. T., Derryberry, D., Anderson, M. O., \& Hruska, R. C. (2012). Spectroscopic detection of nitrogen concentrations in sagebrush. Remote Sensing Letters, 3, 285-294.

Monsen, B., Stevens, R. \& Shaw, N. L (2004). Restoring western ranges and wildlands. RMRS - GTR. Gen. Tech. Rep., vol. 2. (pp. 295-698) : U.S. Dept. of Ag, FS, RMRS + index

Mortimore, M. with contributions from S. Anderson, L. Cotula, J. Davies, K. Faccer, C. Hesse, J. Morton, W. Nyangena, J. Skinner, and C. Wolfangel (2009). Dryland Opportunities: A new paradigm for people, ecosystems and development (pp. 1-2). Switzerland: IUCN; United Kingdom: IIED, and Kenya: UNDP/DDC.

Mundt, J., Glenn, N., Weber, K., \& Pettingill, J. (2006b). Determining target detection limits and accuracy delineation using an incremental technique. Remote Sensing of Environment, 105, 34-40.

Mundt, J. T., Streutker, D. R., \& Glenn, N. F. (2006a). Mapping sagebrush distribution using fusion of hyperspectral and lidar classifications. Photogrammetric Engineering and Remote Sensing, 72, 47-54.

Mutanga, O., Skidmore, A. K., \& Prins, H. H. T. (2004). Predicting in situ pasture quality in the Kruger National Park, South Africa, using continuum-removed absorption features. Remote Sensing of Environment, 89, 393-408.

Okin, G. S., Roberts, D. A., Murry, W., \& Okin, W. J. (2001). Practical limits on hyperspectral vegetation discrimination in arid and semi-arid environments. Remote Sensing of Environment, 77, 212-225.

Ollinger, S. V. (2011). Tansely review: Sources of variability in canopy reflectance and the convergent properties of plants. New Phytologist, 189, 375-394.

Ollinger, S. V., Richardson, A. D., Martin, M. E., Hollinger, D. Y., Frolking, S. E., Reich, S. E. et al. (2008). Canopy Nitrogen assimilation and albedo in temperate and boreal forests: functional relations and potential climate feedbacks. Proceedings of the $\mathrm{Na}$ tional Academy of Sciences, 105, 19336-19341.

Ollinger, S. V., \& Smith, M. L. (2005). Net primary production and canopy nitrogen in a temperate forest landscape: An analysis using imaging spectroscopy, modeling and field data. Ecosystems, 8, 760-778.

Pastor, J., Aber, J. D., McClaugherty, C. A., \& Melillo, J. M. (1984). Above-ground production and $\mathrm{N}$ and $\mathrm{P}$ cycling along a nitrogen mineralization gradient on Blackhawk Island, Wisconsin. Ecology, 65, 257-258. 
Petisco, C., Garcia-Criado, B., Mediavilla, S., de Aldana, B. R. V., Zabalgogeazcoa, I., \& Garcia-Ciudad, A. (2006). Near-infrared reflectance spectroscopy as a fast and nondestructive tool to predict foliar organic constituents of several woody species. Analytical and Bioanalytical Chemistry, 386, 1823-1833.

Polley, H. W., Emmerich, W., Bradford, J. A., Sims, P. L., Johnson, D. A., Saliendra, N. Z., et al. (2010). Physiological and environmental regulation of interannual variability in $\mathrm{CO}_{2}$ exchange on rangelands in the western United States. Global Change Biology, $16,990-1002$.

Press, W. H., Teukolsky, S. A., Vetterling, W. T., \& Flannery, B. P. (1992). Numerical Recipes in C: The Art of Scientific Computing. (2nd ed.). New York: Cambridge University Press (Chapter 3).

Reich, P. B., Ellsworth, D. S., Walters, M. B., Vose, J. M., Gresham, C., Volin, J. C., et al. (1999). Generality of leaf trait relationships: A test across six biomes. Ecology, 80, 1955-1969.

Scott, N. A., \& Blinkley, D. (1997). Foliage litter quality and annual net N mineralization: Comparison across North American forest sites. Oecologia, 111, 151-159.

Serr, K., Windholz, T., \& Weber, K. (2006). Comparing GPS receivers: a field study. URISA Journal, 18, 19-23.

Serrano, L., Penuelas, J., \& Ustin, S. (2002). Remote sensing of nitrogen and lignin in Mediterranean vegetation from AVIRIS data: Decomposing biochemical from structural signals. Remote Sensing of Environment, 81, 355-364.

Skidmore, A. K., Ferwerda, J. G., Mutanga, O., Van Wieren, S. E., Peel, M., Grant, R. C. et al. (2010). Forage quality of savannas - Simultaneously mapping foliar protein and polyphenols for trees and grass using hyperspectral imagery. Remote Sensing of Environment, 114, 64-72.

Smith, M. L., \& Martin, M. E. (2001). A plot-based method for rapid estimation of forest canopy chemistry. Canadian Journal of Forest Resources, 31, 549-555.

Smith, M. -L., Ollinger, S. V., Martin, M. E., Aber, J. D., Hallett, R. A., \& Goodale, C. L. (2002). Direct estimation of aboveground forest productivity through hyperspectral remote sensing of canopy structure. Ecological Applications, 12, 1286-1302.

Suring L. H., Rowland, M. M. \& Wisdom, M. J. (2005). Identifying species of conservation concern. In M. J. Wisdom, M. M. Rowland, \& L. H. Suring (Eds.), Habitat threats in the sagebrush ecosystem: methods of regional assessment and applications in the Great Basin (pp. 150-162). Alliance Communications Group, Lawrence, KS.

Townsend, P. A., Foster, J. R., Chastain, R. A., Jr., \& Currie, W. S. (2003). Application of Imaging Spectroscopy to Mapping Canopy Nitrogen in the Forests of Central Appalachian Mountains using Hyperion and AVIRIS. IEEE Transactions on Geoscience and Remote Sensing, 41, 1347-1354.

Wessman, C. A., Aber, J. D., \& Peterson, D. L. (1989). An evaluation of imaging spectroscopy for estimating forest canopy chemistry. International Journal of Remote Sensing, 10, 1293-1316.

Williams, P., \& Norris, K. (1987). Near-infrared technology in the agricultural and food industries. USA: MN: American Association of Cereal Chemists, Inc.

Yin, X. (1992). Empirical relationships between temperature and nitrogen availability across North American forests. Canadian Journal of Forestry, 22, 707-712. 